\title{
DIBUJOS Y PROYECTOS DE TRESGUERRAS
}

\author{
P O R
}

F R A N I S C O DE LA MA Z A

I A fama de Francisco Eduardo Tresguerras se debe, principalmente, a la LA tradicional y repetida frase de que fue "el Miguel Angel mexicano". Es decir, que como el egregio artista florentino, fué arquitecto, escultor, pintor, poeta y músico.

Sin embargo; conociéndole de cerca, se nos caen de las manos su escultura, su piṇtura, su poesía y su música. En un romance que dedicó a un amigo suyo en el manuscrito de sus Ocios nos dice que:

$$
\begin{aligned}
& \text { "Tresguerras aquel th amigo } \\
& \text { que en maniobras bien distintas } \\
& \text { equivoca su incumbencia } \\
& \text { porque a tantas se destina..." }
\end{aligned}
$$

$Y$ es verdad, a pesar suyo. Como escultor fué un frio neoclásico que no salió nunca de las reglas acedémicas. No logró adquirir una personalidad, en este sentido, como Manuel Tolsá. Como pintor, salvo su autorretrato, unas grisallas de San Francisco y Tercer Orden de Celaya y algunos paisajes, no pasó de un buen aficionado. Como poeta no existe. 
Como músico menos. Harto significativa es la leyenda que se contaba en Celaya, a propósito de la música, de que una vez que ensayaba la flauta ante la Virgen de los Dolores, de quien era muy devoto, le dirigió la palabra la propia Virgen y le dijo: "Por amor de mi Hijo no toques, Francisco, porque me atormentas más."

Tresguerras fué, ante todo, un arquitecto. Pero tambiếh fué un excelente dibujante. Creo que, después de la arquitectura, su sensibilidad mayor estaba en el dibujo, al cual hizo tan poco caso que sólo le sirvió de distracción o de antecedente para sus proyectos arquitectónicos. Sin embargo, pocas veces encontramos en artistas mexicanos del virrcinato esa soltura, esa gracia, esa nerviosidad displicente y de buen gusto que caracterizan los dibujos de Tresguerras. Hubo finos dibujantes y grabadores académicos de la época del celayense, pero ninguno como él manejó la línea con tanta belleza y con tanta libertad, muy lejos de los cánones que sí se impuso en la pintura.

El movimiento de la linea de Tresguerras es como su letra, como sus escritos, como su vida, lleno de una cordial sensibilidad humana, un tanto artificiosa a veces pero siempre emotiva, siempre cálida y sugerente. Basta cxaminar un dibujo de Tresguerras para darse cuenta de que fué una existencia poética y a la vez irónica; ingenua y pintoresca pero a la vez profunda, llena siempre de un contenido plenamente humano, sin rigideces ni prejuicios. El dibujo de Tresguerras es la huída del canon, de la ley académica, que aprisiona en leyes y decretos la voluntad cstética del hombre; es como una reacción al compromiso contraido, fatalmente, al ambiente artístico que imperaba cuando le tocó vivir. ¡Lástima que lo dejara en segundo término y perdiera su tiempo en otras cosas!

Nada tan dificil como el gustar honda y sinceramente de la magia del dibujo, "del Dibujo que todo lo comprende", como decía el propio Tresguerras. Hacer con la sola línea una obra de arte, sin los otros elementos de las clemás artes plásticas, es ya un mérito que pocos artistas logran. $Y$ hay ocasiones en que un dibujo de Lconardo, de Rembrandt, Durero o Picasso vale más que una de sus pinturas. En Tresguerras su línea vale más que todas sus pinturas juntas.

Nada se ha publicado, que yo sepa, de los dibujos de Tresguerras; por lo que creo interesante dar a conocer algunos que se conservan en un cartapacio de la sección de manuscritos del Museo Nacional. 
El primero es una alegoria de las estaciones del año, conservándose solamente las de otoño y estío, representadas por dos niños o amorcillos que llevan por símbolos, el primero un racimo de uvas; el segundo una hoz y una gavilla de trigo. Emergen los niños de unos roleos de marcado estilo rococó, con ese irremediable barroquismo subconciente que nunca pudo dejar el conciente neoclásico Tresguerras. Parecen ser obras de juventud, de extrema juventud. Hay torpeza y descuidos; pero ya se nota esa gana de movimiento, de que he hablado antes, en el gustoso desparpajo de los acantos retorcidos y en la gracia picaresca del angeluco del otoño.

Los siguientes dibujos son parte de un Via Crucis que tal vez sean esbozos para grabados. Son "a la manera de Klauber", es decir, copias, muy personales y menos académicas de los grabados, tan usuales en su epoca, de esa fecunda familia de artistas alemanes. Son las "estaciones" v, VI, XI, XII, XIII y XIV.

Hay un temblor nervioso lleno de emoción y cariño en estos pasos del camino del calvario. La $v$, la de Cristo con su cruz a cuestas ayudado por el Cirineo, tiene una ligereza extraordinaria. La faz de Jesús se ensombrece y mira fijamente al espectador en demanda de misericordia; los sayones se mueven en perspectiva, desde la pobre humanidad del Cirineo y la figura intermedia entre él y el Cristo, hasta la lejania rocosa del desolado paisaje que se adivina al fondo.

La vi es la escena de la Verónica disponiéndose a limpiar el ensangrentado y sudoroso rostro de Jesús. Los verdugos hacen un movido marco alrededor y esgrimen y cruzan sus lanzas, que parecen, con gracioso desenfado, temblorosos tallos. Las rocas del fondo anuncian ya el Gólgota, coronado de soldados.

La xI es la crucifixión, en la cual la desnuda Víctima alarga sus brazos y piernas que clavan sayones judios, mientras los soldaos romanos esperan.

La XII es la escena del Calvario, con sus eternos personajes: el buen ladrón, erguido en su cruz, levantada la cabeza, pide perdón; el mal ladrón, cadente y retorcido, atrás del Cristo, soporta su incrédula agonía. La Virgen, San Juan y la Magdalena llevan sus posturas teatrales de tradición, así como el Cristo que reposa en su cruz sin tragedia. Creo que hay menos cmoción en este dibujo, tal vez por la repetición secular del terma. 
La XIII es el descendimiento, con su grupo de mujeres que sostienen el cadáver. La figura mejor lograda es la Magdalena, de pie, con el histórico pelo suelto sobre la espalda, como continuando los girones de "la sábana santa en la cual fué envuelto..." que pende aún de la cruz.

La xiv es el entierro y aquí Tresguerras se desata. Por fin el arquitecto Tresguerras puede dibujar arquitectura. Cristo es enterrado bajo una bóveda rota sostenida por un arco a manera de arbotante. El piso se rompe también y todo es ruina, a pesar de la coquetería renacentista del jarrón que reposa en una piedra. Las figuras, al centro, se mueven al compás de los arcos y se inclinan ante el cadáver que depositan en la roca. No sé si de Klauber o de Tresguerras es el olvido de que el sepulcro de Jesús fué simplemente un geométrico agujero "labrado en la peña" y con una gran piedra como tapa, sin la menor idea arquitectónica; pero es natural que la imaginación haga una romántica sepultura en unas ruinas abandonadas, evocadoras de restos clásicos, gusto tan frecuente en los artistas del renacimiento y en sus hijos póstumos, los artistas del neoclásico.

Los dibujos siguientes son dos bocetos arquitectónicos. El primero es una mesa de altar en forma de urna, tan en boga en el renacimiento y en el neoclásico, recordando los entierros cristianos primitivos, con todos sus elementos finamente dibujados y sombreados, así como la puerta monumental para capilla del segundo, con un gran arco formado sin interrupción por grandes sillares de piedra; el remate es una espadaña complicada, con frontón y cupulín y adornada con esas molduras en caracol que tanto usó Tresguerras en todas partes. No sé si llegaron a realizarse estos bocetos; ni tampoco los dos siguientes, que son dos altares. El primer proyecto lo firmó: "Eduardo Fernández lo inventó y dibuxó", que no es más que un apócope de su nombre: Francisco Eduardo Fernández Tresguerras. Como vivía en pleito contínuo con sus compañeros los "arquitetes", como él les decía, tal vez para engañarlos o evitar sus críticas, muchas veces debe haber firmado con otros nombres stus proyectos. Es este un altar que nos recuerda vivamente los que ejecutó en San Francisco de Celaya, con las pequeñas pinturas que él mismo hacia y la indispensable Virgen de los Dolores enmedio.

La mesa del altar se sostiene por las molduras de caracol, y a los lados tábleros con unos clavos que sostienen paños colgantes. El zócalo del primer cuerpo lleva medallones pintados, asi como los intercolumnios 
se forman de dos pinturas cada uno. La imagen central, como en recuerdo de los retablos del siglo xvir, se devela tras una cortina que se enrrolla a los lados; sobre el frontón curvo del remate chorrean otra vez las molduras de caracol. Arriba una ráfaga enmarca a la Trinidad, mientras un gran arco con recuadros y adornos hace fondo a todo el altar. Para completar el proyecto van, en la parte de abajo, la planta, y en la de arriba las medidas: "Pitipié de dos baras regulares con el pormenor de dedos por derecho y en la diagonal."

El segundo proyecto es un retablo muy parecido a los altares que erigió en el templo del Tercer Orden de su ciudad natal. Aquí va un nicho central para pintura y a los lados las estatuas de San Pedro y San Pablo. El remate es de un declarado barroco, aunque tal vez la intención de Tresguerras fué hacer obra clásica; rompe desaforadamente el frontón para poner un flamero o maceta; lo adorna con molduras $y$ festones y lo mueve tanto que desequilibra la serenidad del cuerpo del altar. Vuelve aquí al dibujo nervioso y rápido, no al pulido y razonado del anterior altar de Dolores. Parece, más que un retablo, un proyecto de portada para realizarse en piedra.

El último proyecto que publico es de sumo interés, por ser el de la parte central del altar mayor del templo del Carmen, en Celaya, su obra arquitectónica más conocida y más famosa.

El día 4 de noviembre de 1802, el alférez real de la villa de Celaya, don Juan Gregorio Bosque, ponía la primera piedra del nuevo y tercer templo de los carmelitas descalzos. El día 13 de octubre de 1807 se dedicaba, apadripando el acto el Aytuntamiento, bendiciéndolo el deán de Valladolid y diciendo la primera misa el prior fray José de San Fermín. El ayudante de la solemne misa no fué el acólito de siempre, sino el autor de la iglesia, el arquitecto Tresguerras.

El mismo ha descrito su obra: "Por dentro es de orden corintio, como que es su patrona María Santísima, mas los altares que están embutidos son como piezas independientes; van afinándose por grados, así en sús adornos como en sus órdenes hasta que el altar mayor, reuniendo y realizando los perisamientos se presenta serio, rico y majestuoso, siendo con la decoración general un trozo poco común, mas no desenlazado, así que su corniza; es un ándito cómodo, a nivel con la que circunda toda la iglesia 
y resguarda un balaustro dorado, sin que interrumpa, ni menos padezca más quiebros que los necesarios según arte." 1

Este trozo es muy importante para darnos cuenta de las ideas estéticas de los artistas del neoclásico. Desde luego prosiguen inconcientemente, cuando menos Tresguerras, el simbolismo barroco simbolismo no comprendido y destruido por ellos pero que les dió tantas bases. El poner el orden corintio, orden femenino por excelencia según los tratadistas tradicionales, para glorificar a una Virgen, es un sentimiento barroco; también lo es el ir graduando la riqueza y ostentación de los altares hasta llegar al mayor, sede principal que debe superar a los demás ¿ no están concebidos asi Tepozotlán, Tasco, Valenciana, etc.? Del barroco al neoclásico hay un cambio del sentido de la línea y del color, pero persiste un fondo común religioso y estético que los liga. La lucha y el odio entre los dos estilos tiene un origen social y no estético.

Sin embargo fué atacado por sus compañeros, los artifices barrocos, que murmuraron que los planos del Carmen los había recibido de Roma. Eilos concebían ese nuevo estilo clásico sólo en la vieja Roma y les parecía exótico en México; no les cabía en la cabeza que un criollo celayense idease un templo tan diferente a la bisecular tradición mexicana, de fachadas de encaje de piedra y retablos dorados y policromados.

Tresguerras contestó indignado que tenía en su casa los planos hechos de su mano, "así como los dibujos de los altares"; pero claro está que no dijo que se había desvelado estudiando los grabados de los libros de Vitrubio, Palladio, Serlio, Scamozzi, etc., fuentes de donde salen casi todas su obras arquitectónicas.

El diseño de la parte inferior del altar mayor del templo de Celaya está dibujado, como los anteriores, en tinta negra, manchadas a pincel las columnas y sombreado a la acuarela. La línea general del dibujo, elegante y decidida, se afina en las estatuas, en el esbelto y ascético San Juan de la Cruz; en la inquieta y móvil Santa Teresa, "fémina andariega", interpretados por Tresguerras con toda finura, según los diferentes caracteres de los dos reformadores del Carmelo.

El tabernáculo es también de magnífico dibujo, de exquisitas pnoporciones, resaltando airoso sobre el fondo blanco como un tempietto bramantino.

1 En Bosquejo biogrifico de Tresguermas, por Maniud Ramero de Termetes. 


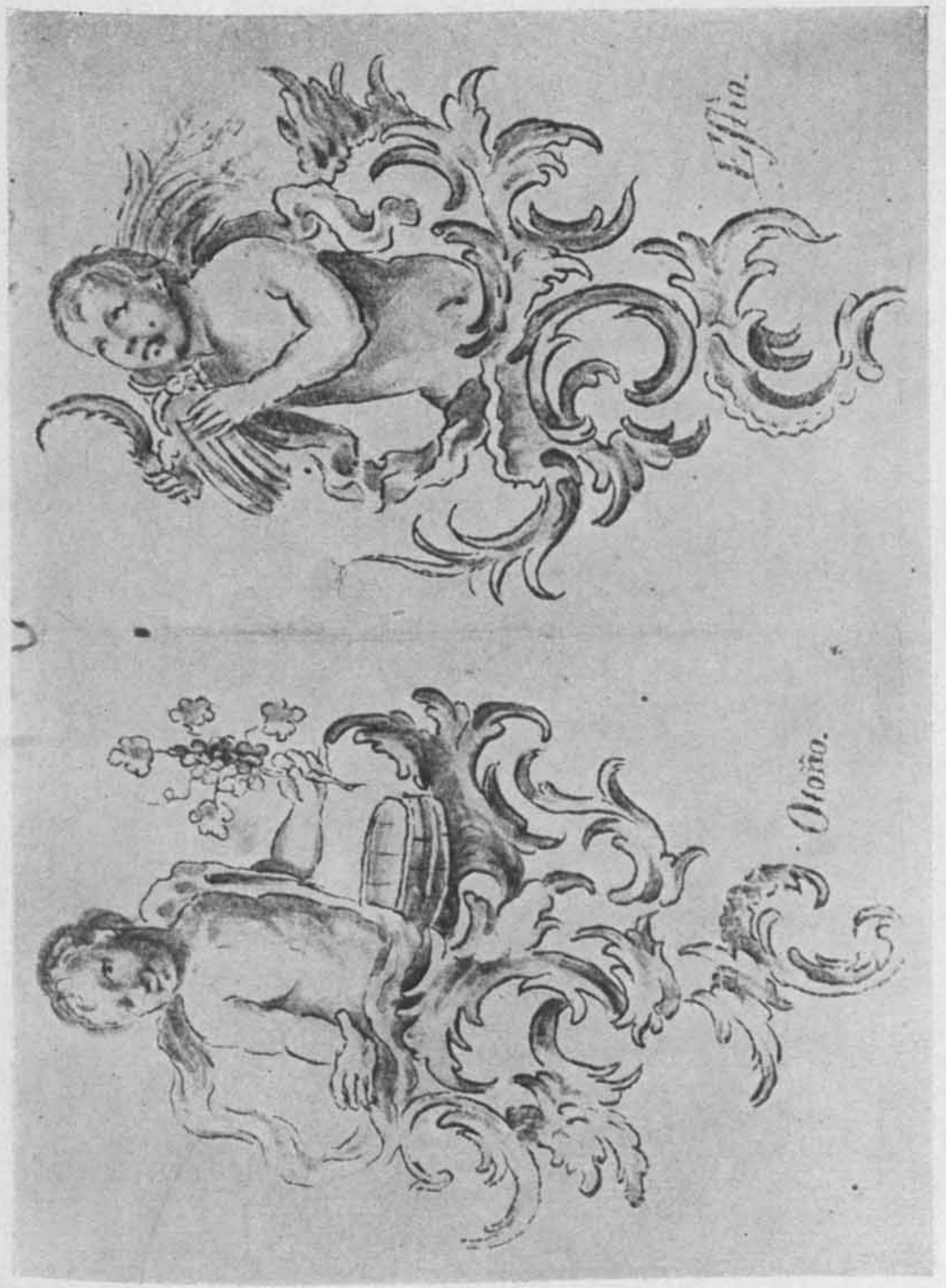

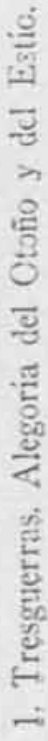


DOI: http://dx.doi.org/10.22201/iie.18703062e.1950.18.504

Statio V.

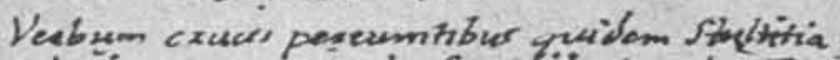

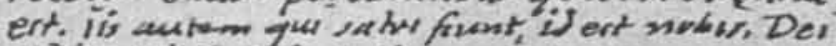
viesw ont I Coki. T. 18

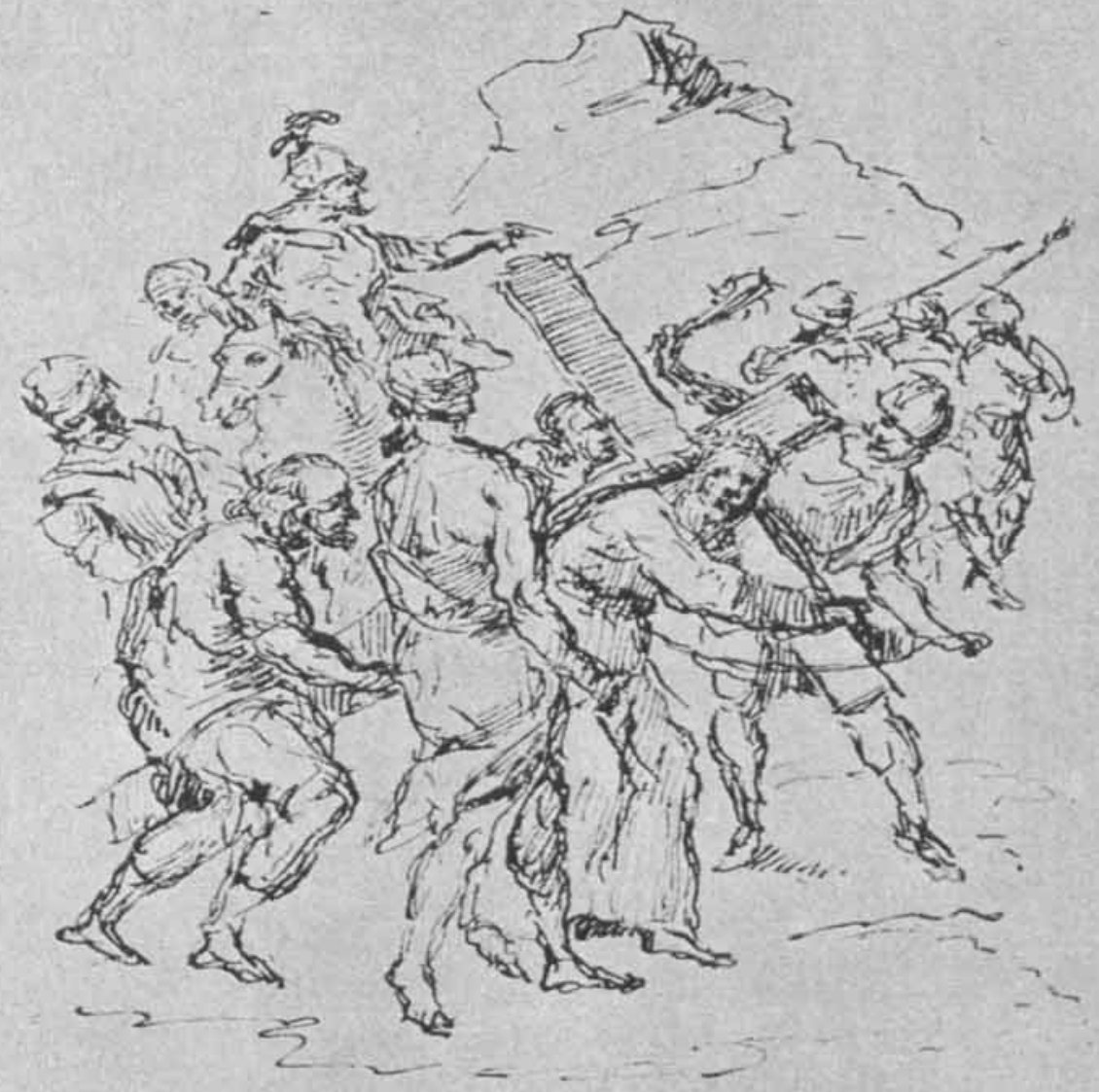

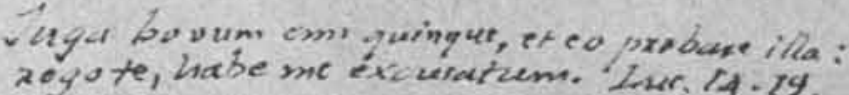

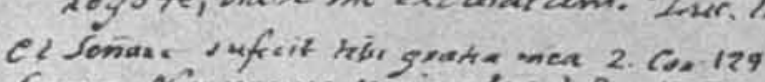

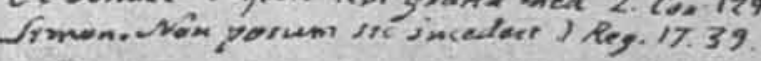

- Imor Caxines

2. Tresguerras. Estación $\mathrm{v}$ del Via Crucis. 


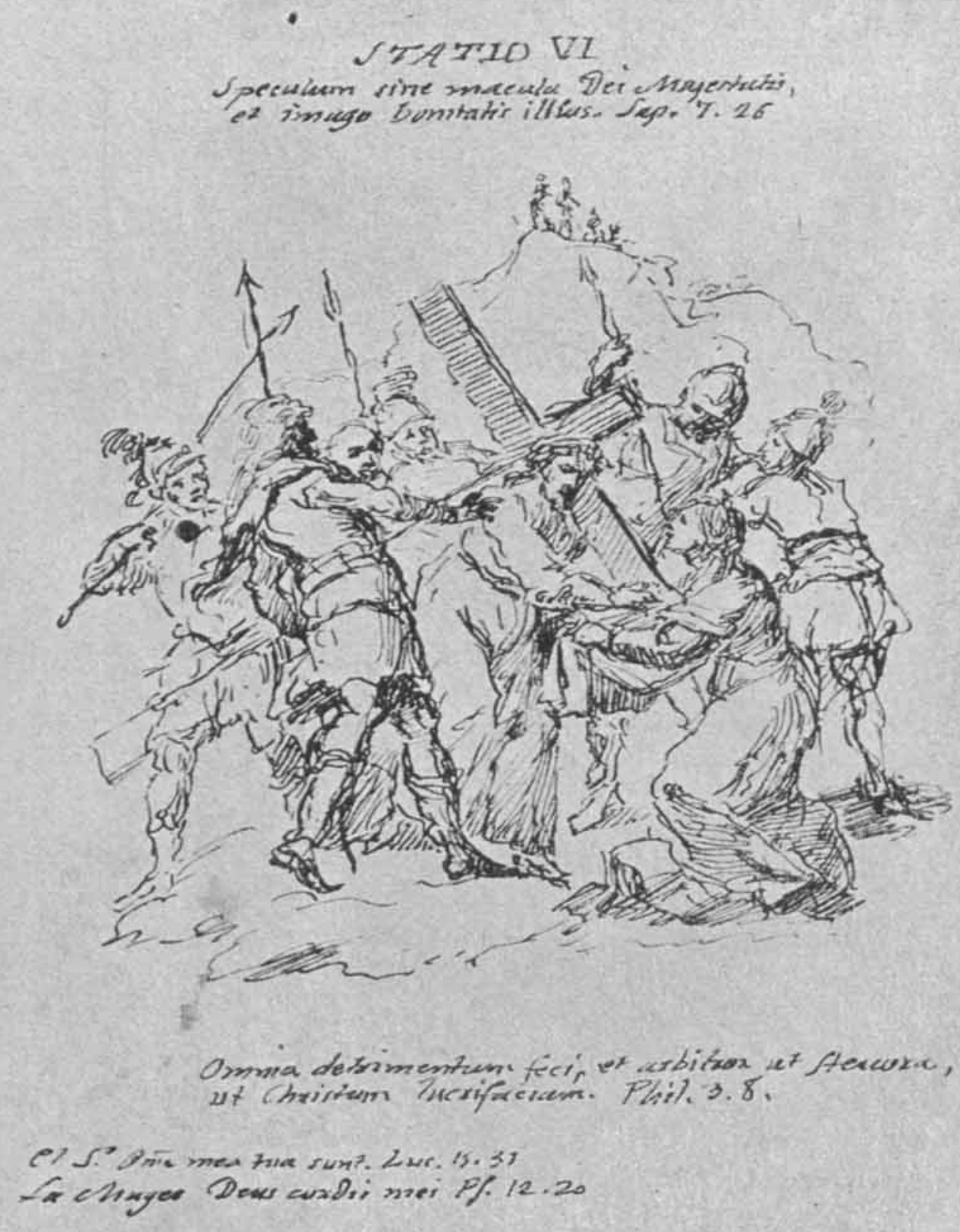

3. Tresguerras. Estación vi del Via Crucis. 
DOI: http://dx.doi.org/10.22201/iie.18703062e.1950.18.504

Statio $V$.

Veabum cxucis pereamnbue ruidom Sthithitia

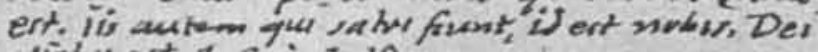

viets ont 1 Coai. 1. 18

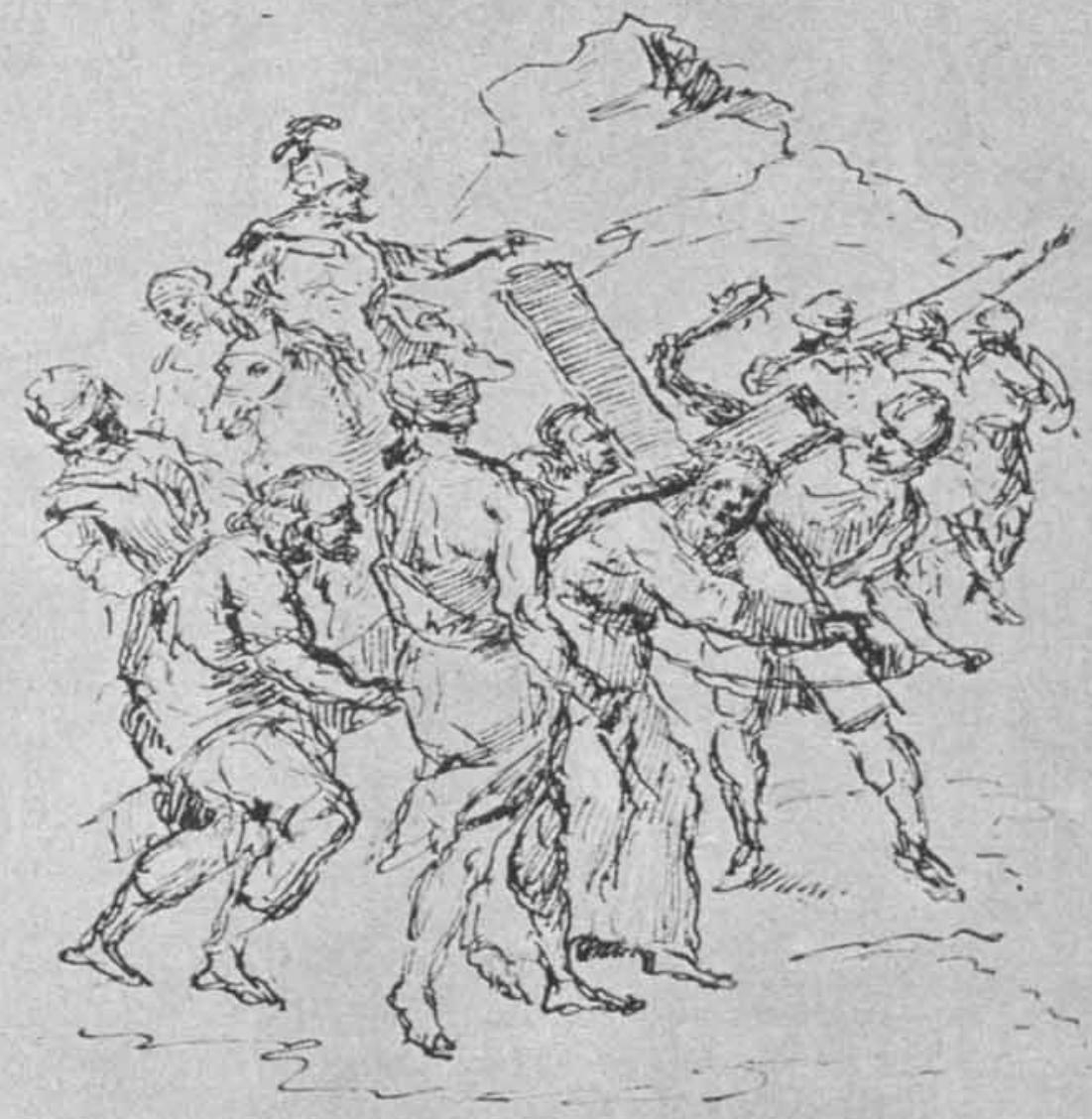

"ugar bovum em quingur, ef eo pxibure illa:

royute, habe me excusatum. Ins. 14.79.

Cl Soñar sufriz his gratia mer 2. Con 129

frmon. Nön porum sre jincedarr J Peg. 17.39.

- Iman Caxines

2. Tresguerras. Estación $\mathrm{v}$ del Via Crucis. 


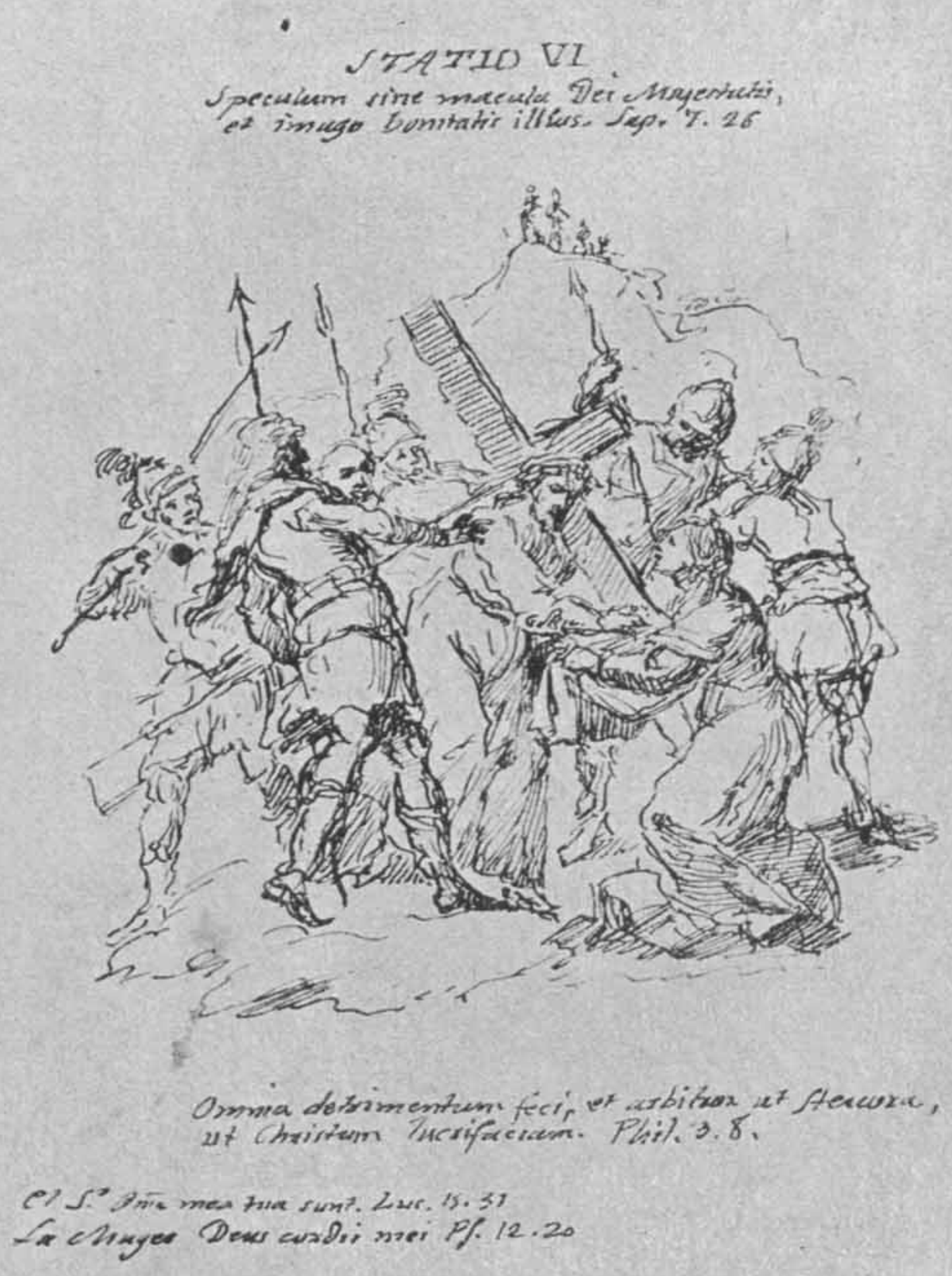

3. Tresguerras. Estación vI del Via Crucis. 
DOI: http://dx.doi.org/10.22201/iie.18703062e.1950.18.504

\section{I'STATIO XI.}

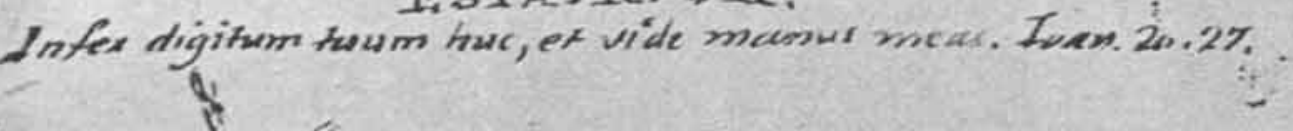

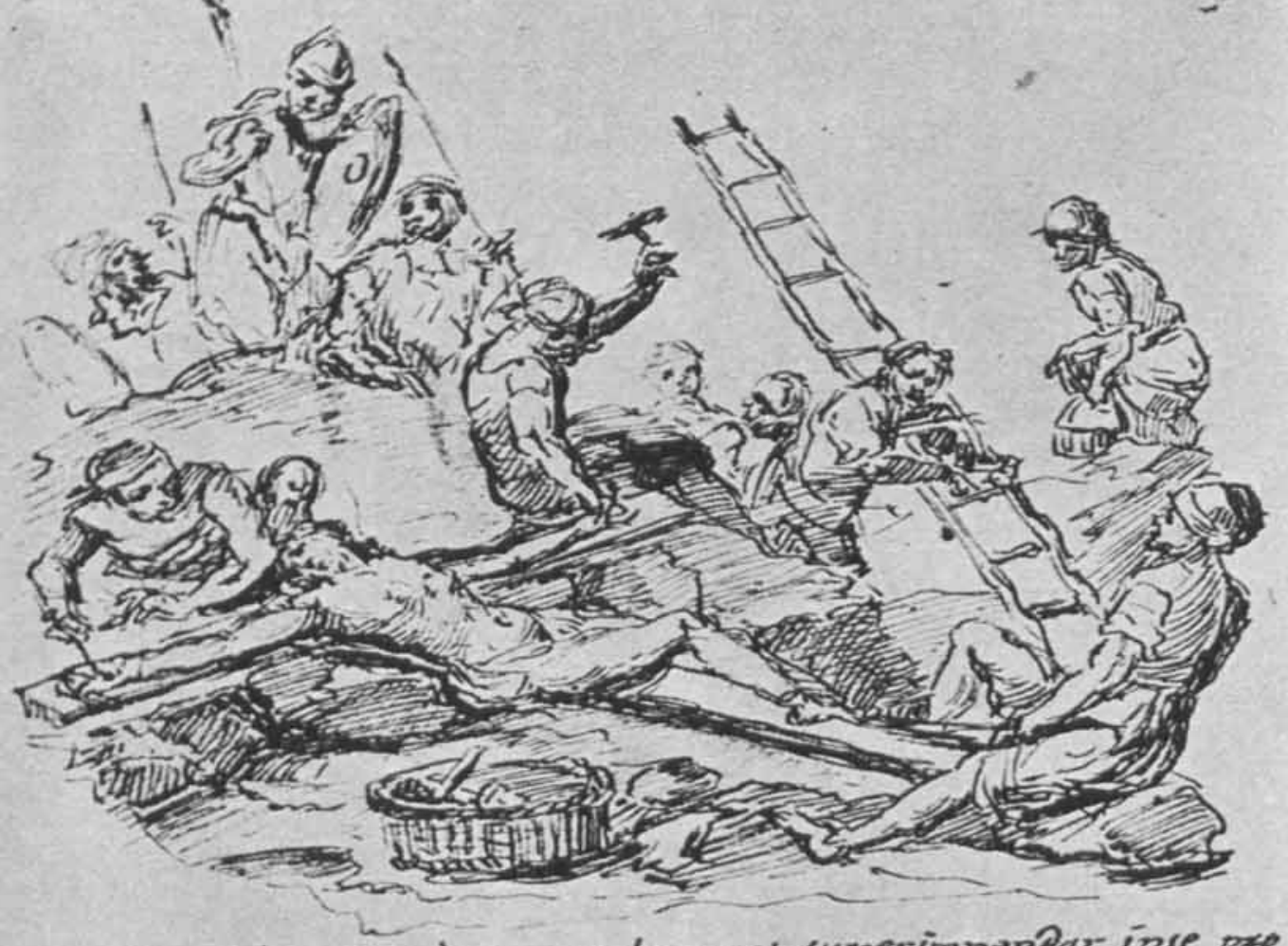

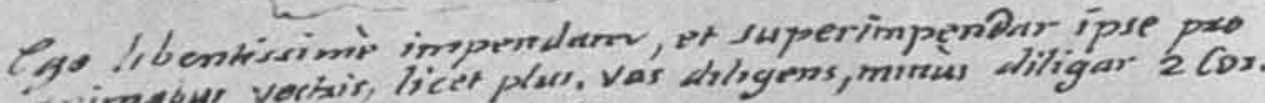

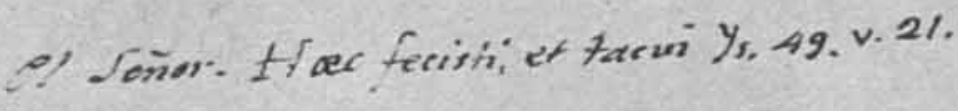

4. Tresguerras. Estación $\mathrm{xr}$ del Via Crucis. 


\section{ESTART( XII}

OSi quis miti daret potum aque de cisternn Bing 23.13

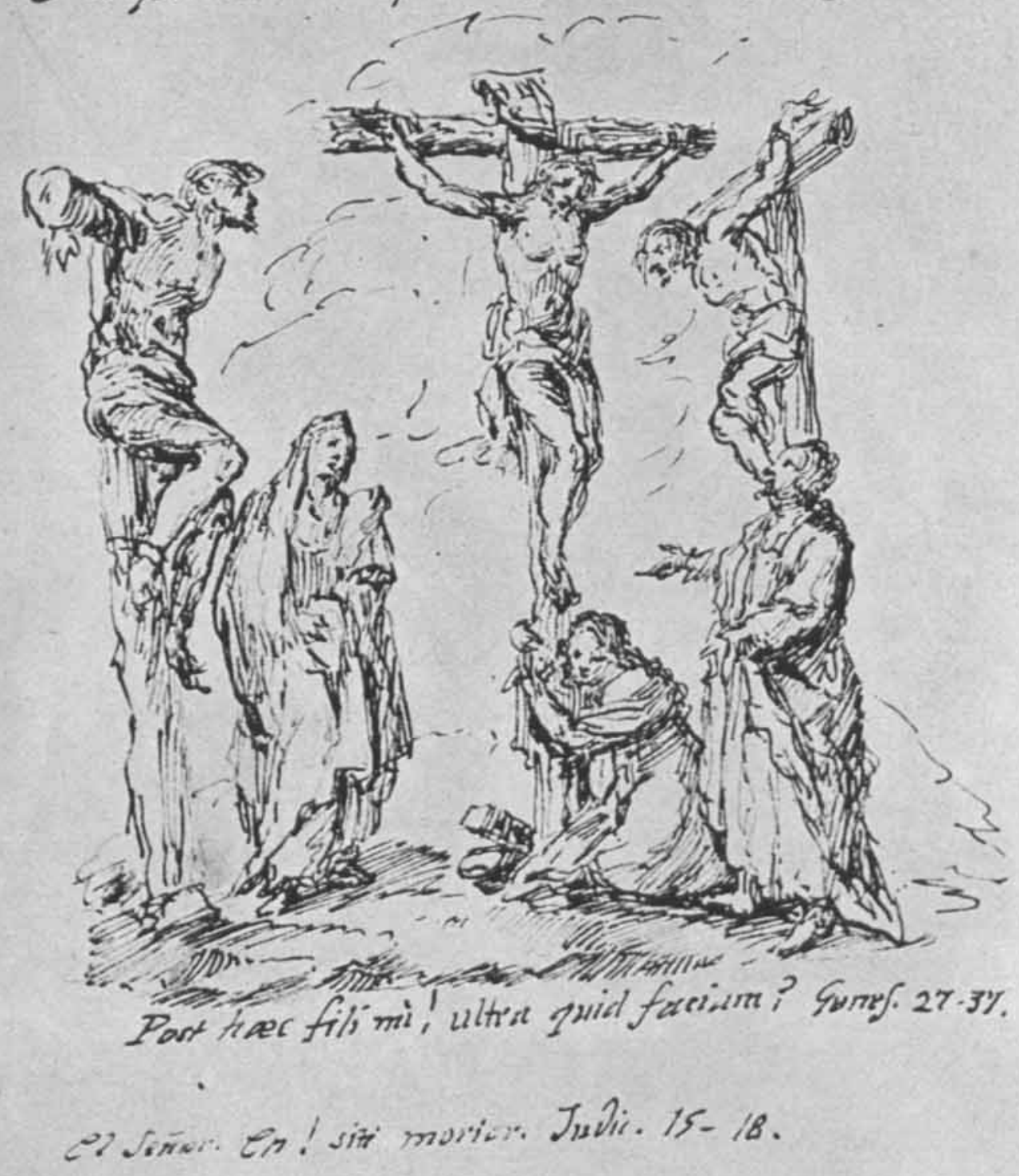

5. Tresguerras. Estación xn deı Via Crucis. 


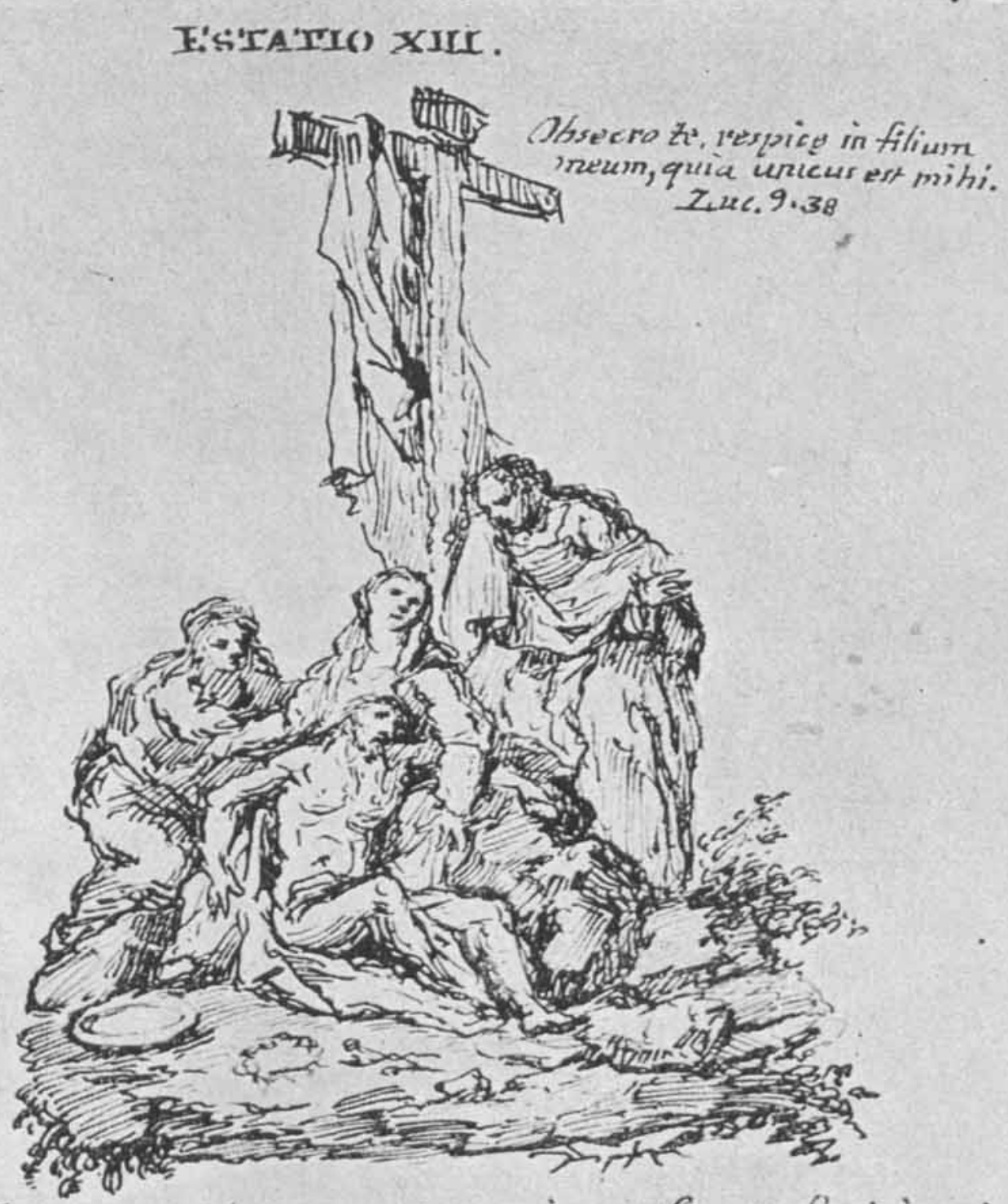

Cuos proscivit et proclestinavit, conformes fieri imaginis filii sui. hum, 8.29 .

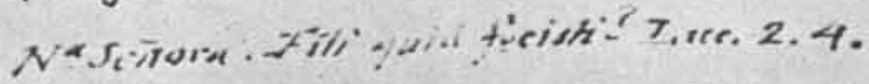

6. Tresguerras. Estación xIII del Via Crucis. 
DOI: http://dx.doi.org/10.22201/iie.18703062e.1950.18.504

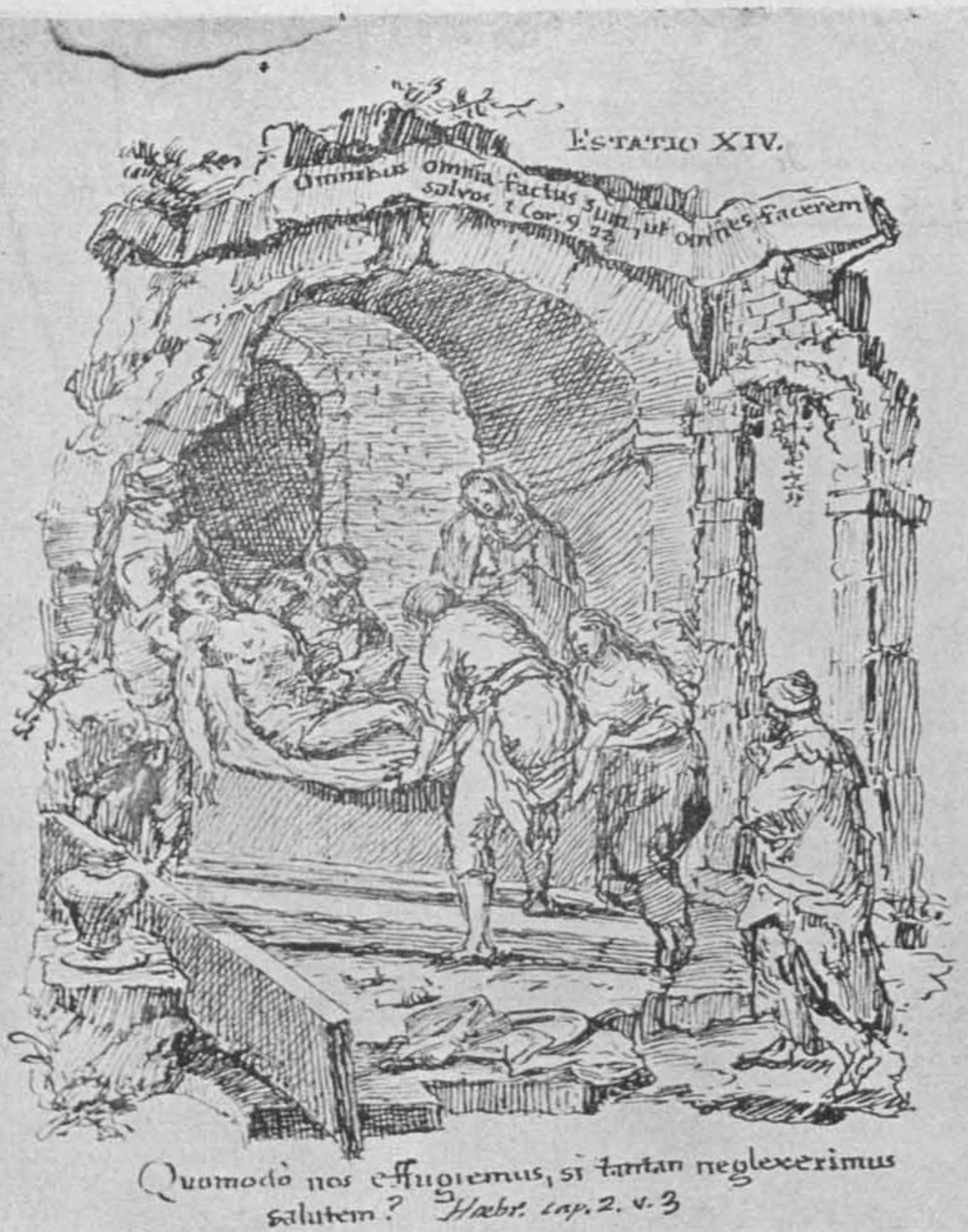

7. Tresguerras. Estación xrv del Via Crucis. 
DOI: http://dx.doi.org/10.22201/iie.18703062e.1950.18.504

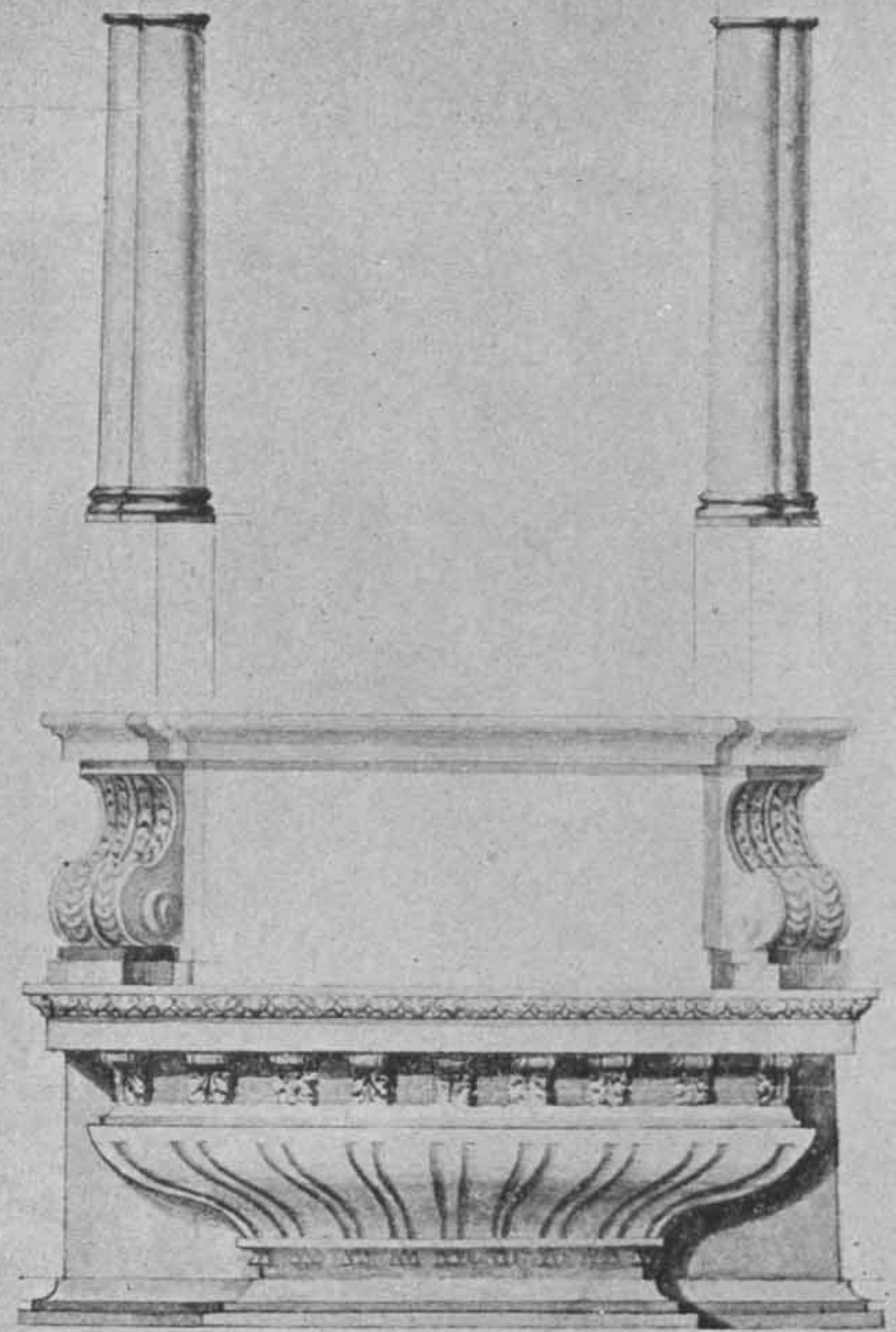

8. Fresguerras. Proyecto de altar. 
DOI: http://dx.doi.org/10.22201/iie.18703062e.1950.18.504

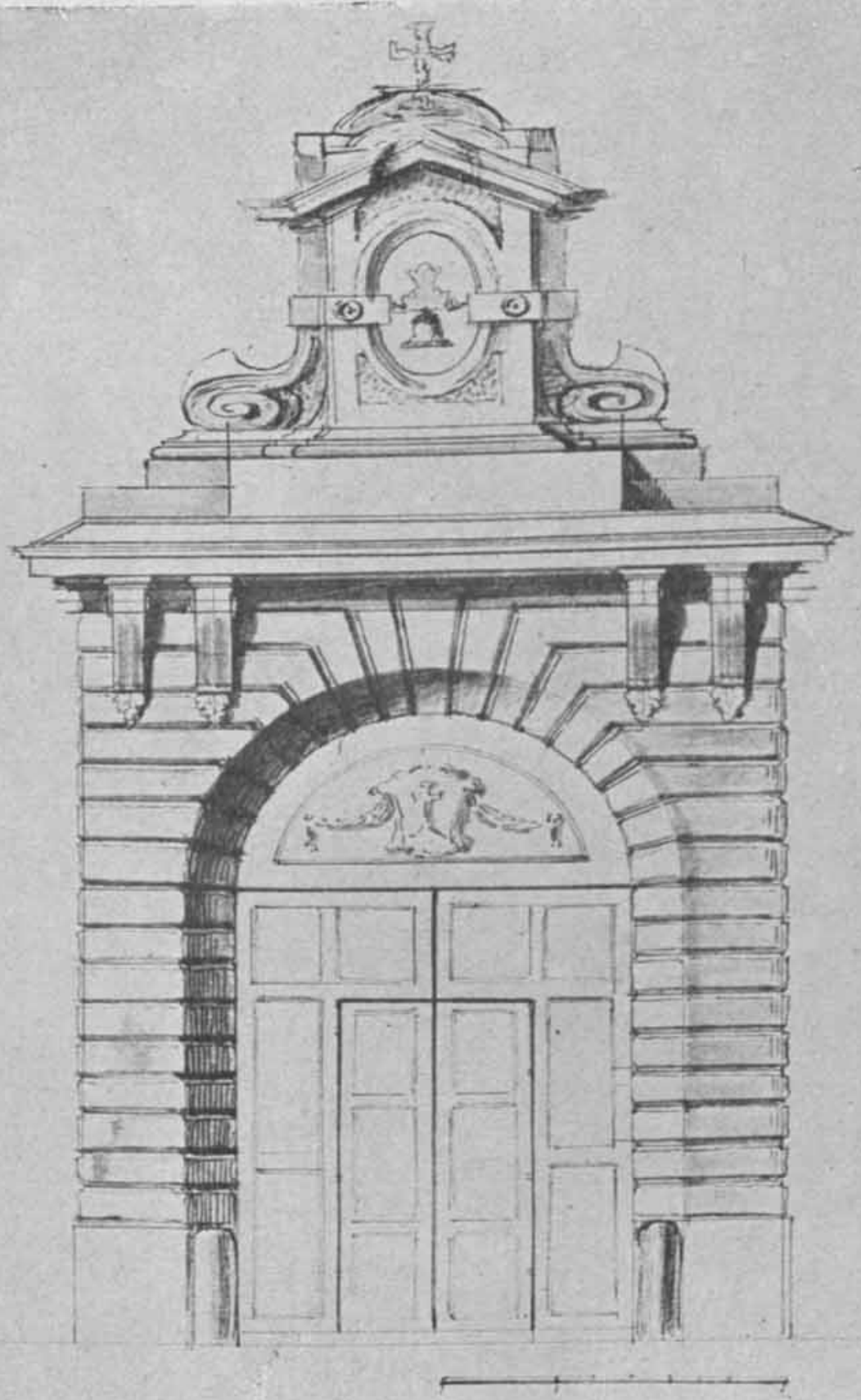

9. Tresguerias. Proyecto de portada de eapil'a. 


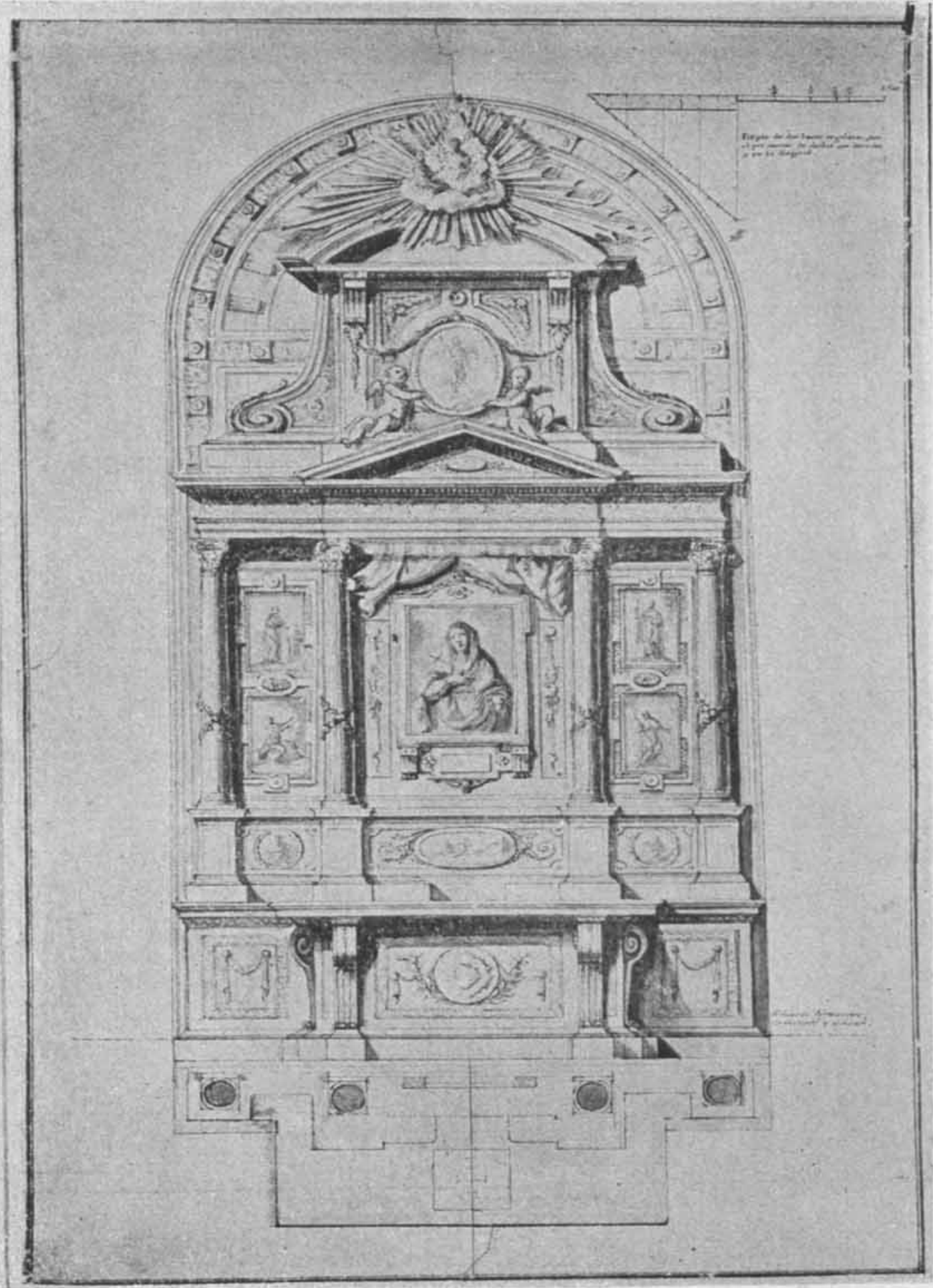

10. Tresguerras. Proyecto de altar. 


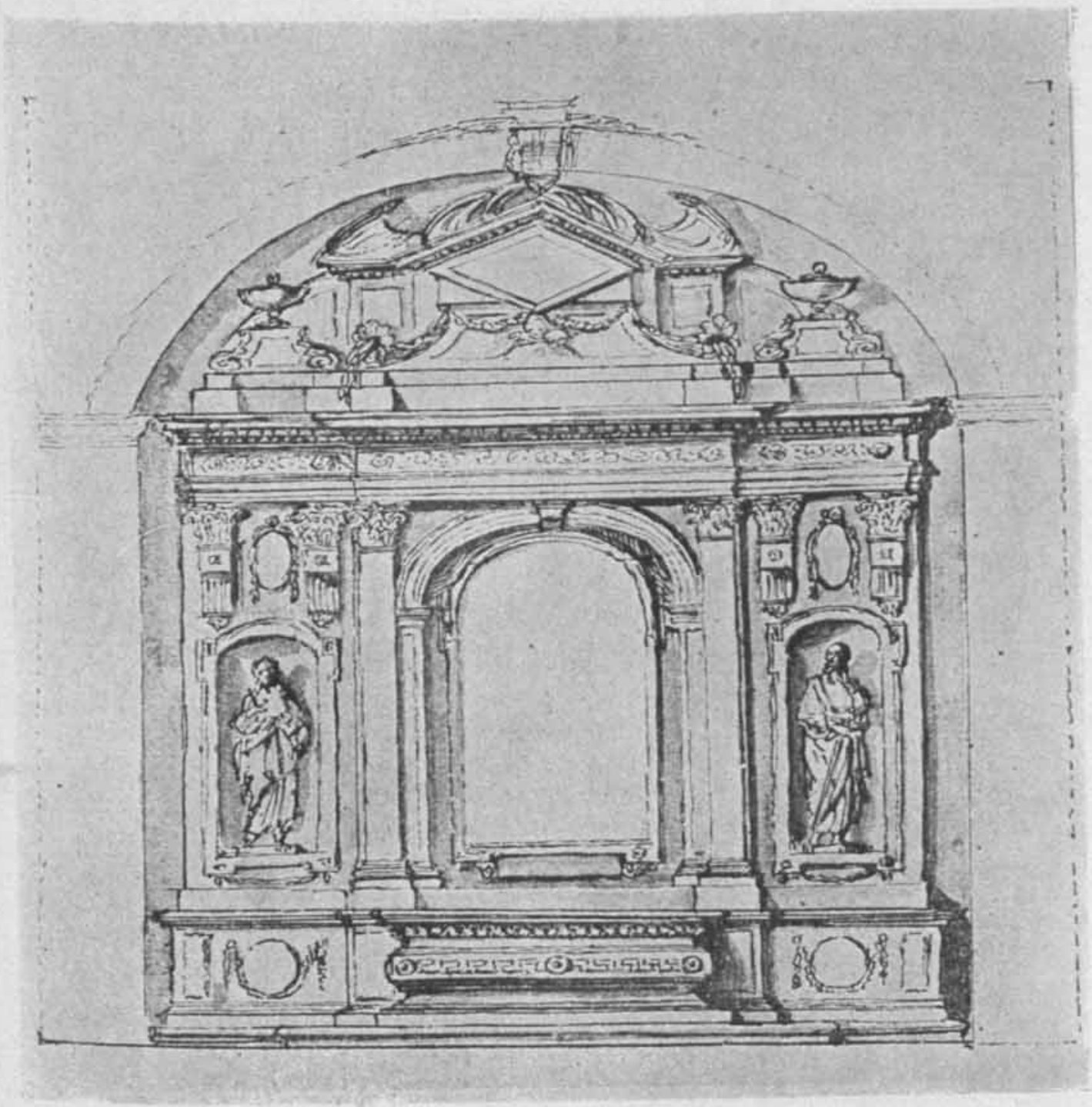

11. Tresguerras. Proyecto de altar. 


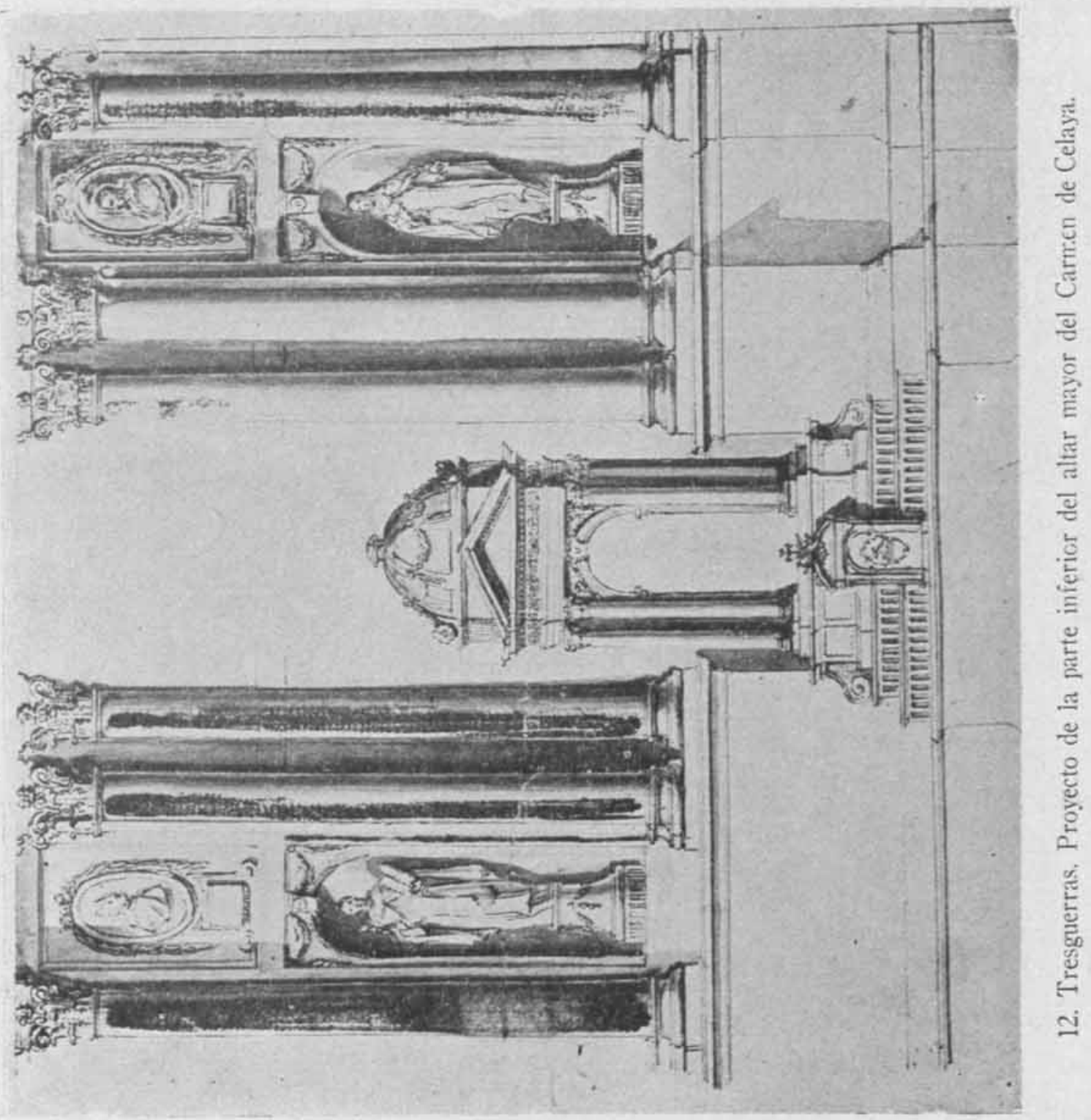


DOI: http://dx.doi.org/10.22201/iie.18703062e.1950.18.504

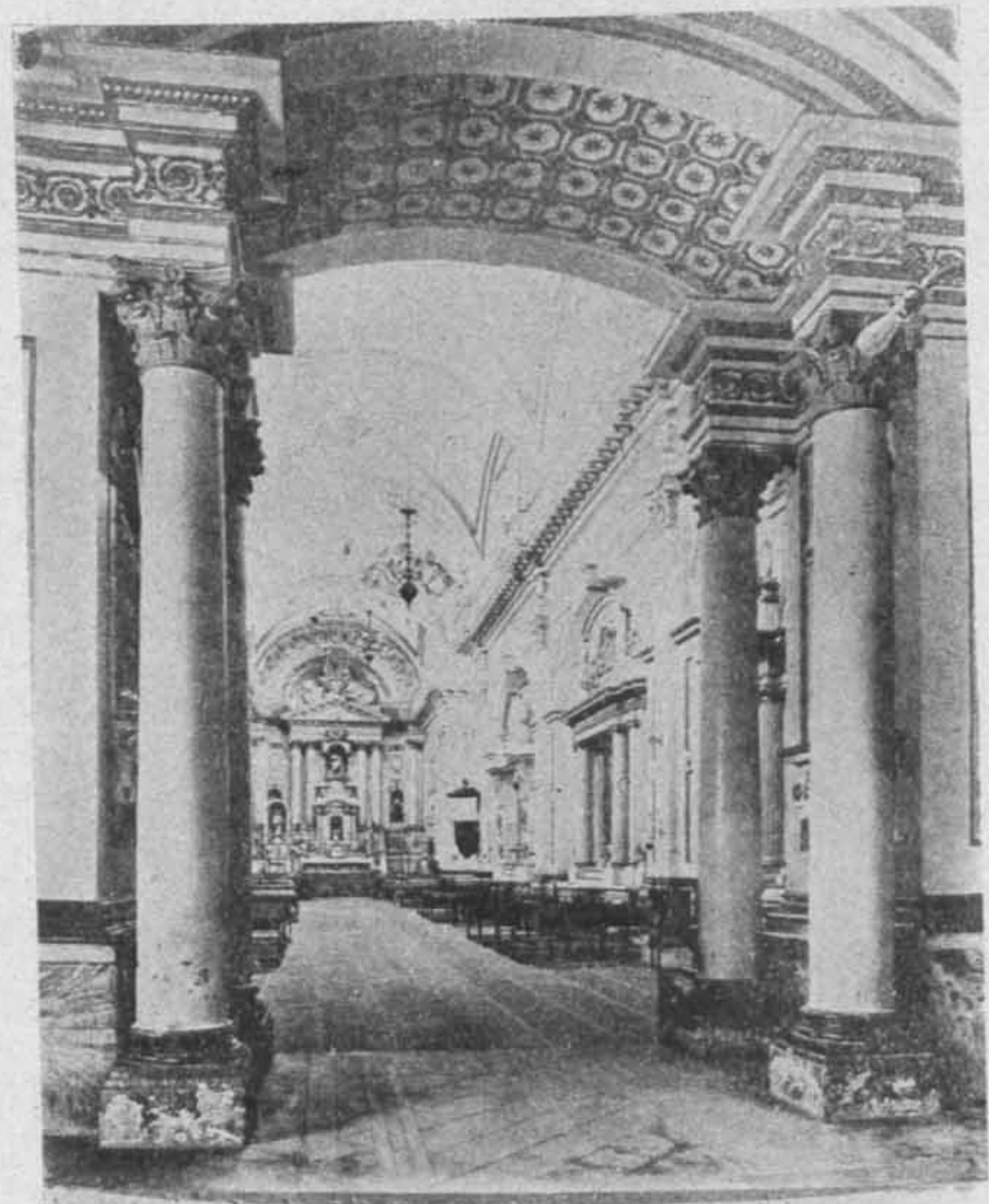

13. Tresguerras. Altar mayor del Carmen de Celaya. 
DOI: http://dx.doi.org/10.22201/iie.18703062e.1950.18.504

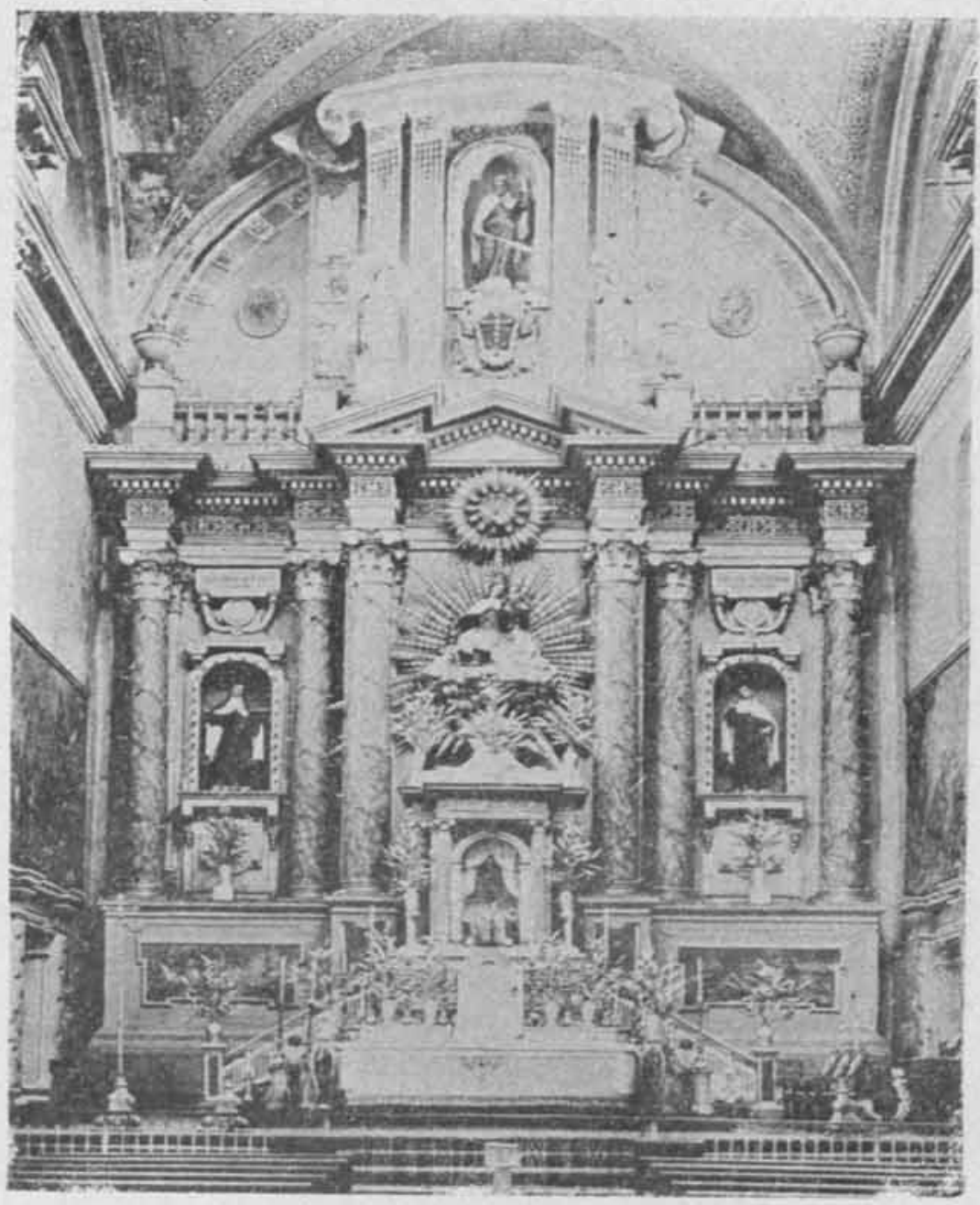

14. Tresguerras. Altar mayor del Carmen de San Luis Fotcsi. 
Las columnas cotintias son seis, cuatro centrales, pareadas, que separan el nicho de la Virgen de los nichos laterales, y dos finales que terminan el altar. Los nichos se inician a la altura de la base de las columnas y terminan en arco de medio punto, acusando la clave, de la cual arrancan festones que adoman las enjutas y chorrean en las aristas finales. Arriba, sobre un recuadro moldurado, dos medallones ovalados, rodeados también de festones de laurel que llevan unos bustos de perfil.

Ya en la realización arquitectónica del diseño se encuentran todos los elementos descritos, salvo algunos adornos del tabemáculo que suprimió, y pequeñas diferencias de proporciones en los recuadros y medallones. Las estatuas, al pasar de la linea al volumen perdieron, por desgracía, casi toda su espontaneidad y elegancia.

Veiente años después, recordando este altar en el que erigió en el Carmen de San Luis Potosi, corrigió muchos detalles, a pesar de la "majestuoso" del de Celaya. Sin duda que, dándose cuenta de la innegable pesadez de conjunto del altar celayense, quiso aliviar al potosino, para lo cual resaltó las dos columnas centrales, evitando as el seguir forzosamente la monótona linea horizontal del entablamento y cortó el frontón, cosa que aunque no era "según arte", pues es una concesión barroca, le dan una gracia y una ligereza muy superiozes al de Celaya. Subió, con razón, los nichos laterales de San Juan y Santa Teresa al centro de los intercolumnios para equilibrar el violento triángulo escultórico que se presenta en Celaya, aprovechando los espacios inferiores para sus aficiones de pintor. El tabernáculo lo usó como sostén de la nube plateada conde reposa la bella Virgen del Carmen, y el remate no logra, en verdad, la magnífica solución del de Celaya.

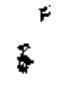

